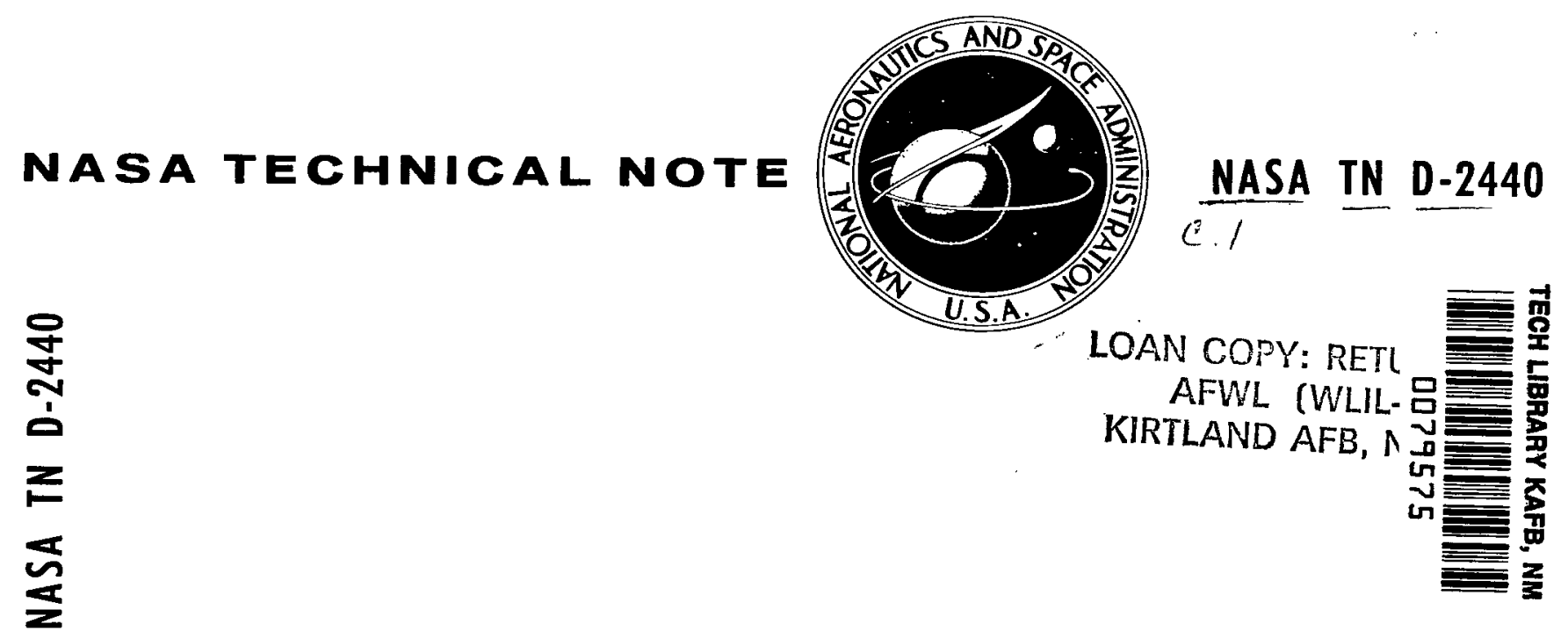

\title{
A POSSIBLE REGENERATIVE, MOLTEN-SALT, THERMOELECTRIC FUEL CELL
}

by Jacob Greenberg, Lawrence $\boldsymbol{H}$. Thaller,

and Donald E. Weber

Lewis Research Center

Cleveland, Obio

NATIONAL AERONAUTICS AND SPACE ADMINISTRATION - WASHINGTON, D. C. AUGUST 1964 
A POSSIBLE REGENERATIVE, MOLTEN-SALT, THERMOELECTRIC FUEL CELL

By Jacob Greenberg, Lawrence H. Thaller, and Donald E. Weber

Lewis Research Center

Cleveland, Ohio 


\title{
A POSSTBLE REGEENERATIVE, MOLTEN-SALT,
}

\author{
THERMOETECTRIC FUET CETL \\ by Jacob Greenberg, Lawrence H. Thaller, \\ and Donald E. Weber \\ Lewis Research Center
}

\begin{abstract}
SUMMARY
Molten or fused salts have been evaluated as possible thermoelectric materials because of the relatively good values of their figures of merit, their chemical stability, their long liquid range, and their ability to operate in conjunction with a nuclear reactor to produce heat. In general, molten salts are electrolytic conductors; therefore, there will be a transport of materials and subsequent decomposition with the passage of an electric current. It is possible nonetheless to overcome this disadvantage by using the decomposition products of the molten-salt electrolyte in a fuel cell. The combination of a thermoelectric converter and a fuel cell would lead to a regenerative system that may be useful.
\end{abstract}

\section{INTRODUCTION}

Salts, such as sodium chloride ( $\mathrm{NaCl}$ ) or zinc chloride ( $\mathrm{ZnCl} \mathrm{I}_{2}$ ), are normally considered to be electrical insulators; however, when the salts are melted, they become excellent electrical conductors. Although electrical transport in fused salts occurs by movement of ions rather than electrons, fused salts have many electrical properties similar to metals and semiconductors. In particular, fused salts show large values of the Seebeck coefficient, or thermoelectric power. The thermoelectric power for ionic conductors has been discussed by de Groot (ref. 1), who showed that it is a function of the following three factors: (I) the thermopotential due to the electrodes at different temperatures, (2) the entropy change due to reactions at the electrodes, and (3) the transference numbers and transport heats of the ions. Measurements of thermoelectric power in fused salts, ranging from 300 to 900 microvolts per ${ }^{\circ} \mathrm{C}$, and interpretation of the results in terms of de Groot's theory are given in reference 2. Consequently, it is natural to consider the possible use of fused salts in thermoelectric engines for the conversion of heat to electricity. 


\section{Molten-Salt Thermoelectric Generator}

It can be shown from a calculation of the thermoelectric figure of merit that molten salts have excellent possibilities as thermoelectric materials. If median values are selected for the Seebeck coefficient, electrical conductivity, and thermal conductivity, a figure of merit is obtained within an order of magnitude of that calculated for the best semiconductor thermoelectric materials.

The use of molten salts in such devices is limited because the passage of current is accompanied by a transport of matter and an electrochemical decomposition of the fused salt. It is possible, however, to incorporate this feature in the design of a combination thermoelectric-electrochemical fuel cell. If the molten-salt thermocell component is constructed so that the cell has inert electrodes, the salt will start to decompose into its components under a thermal gradient when the inert electrodes are externally short-circuited. If the thermoelectric voltage is less than the decomposition potential of the salt, decomposition will cease if the electrolysis products are allowed to collect at the electrodes. These accumulated decomposition products would establish a back electromotive force that would halt further decomposition. If these products are removed, however, decomposition continues. The products then can be recombined at a second pair of electrodes to produce electricity. In the preceding manner, a continuously operating molten-salt thermoelectric generator can be made.

\section{Fuel-CelI Component}

Figure $I$ is a schematic diagram of the regenerative molten-salt thermoelectric fuel cell. The molten salt acts first as a thermoelectric converter

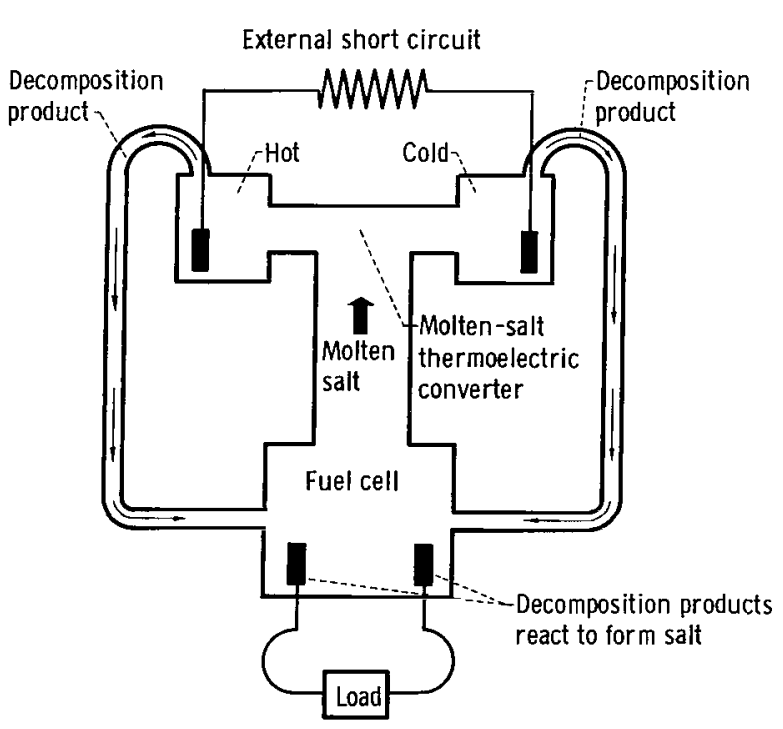

Figure 1. - Schematic diagram of regenerative, molten-salt, thermoelectric fuel cell. to produce electricity from heat. This electricity is allowed to flow through an external short circuit, which results in the electrolytic decomposition of the molten salt. The decomposition products are then physically transported by convection and diffusion to another part of the cell containing a second pair of electrodes. Electrochemical reaction at these latter electrodes produces electricity that can be applied to an external load. This electrochemical reaction regenerates the salt decomposed by the thermoelectric current. It is important to note that the sealed cell is capable of continuous operation for indefinite periods as a result of this last regenerative step. 


\section{System Efficiency}

It can be seen (fig. I) that the system is a thermoelectric generator coupled to a fuel cell by an intermediate step of electrolysis. The overall efficiency $\eta$ of the system in converting heat to electricity is

$$
\eta=\eta_{T} \eta_{E} \eta_{F}
$$

where

$\eta_{\mathrm{T}}$ efficiency of thermoelectric salt in converting heat to electricity

$\eta_{\mathrm{E}} \quad$ efficiency of electrolytic process in converting electricity to chemical energy and transporting it to fuel-cell electrodes

$\eta_{\mathrm{F}}$ efficiency of fuel cell in converting chemical energy to electricity

The following are necessary for maximum efficiency:

(1) Salts with a high thermoelectric figure of merit are required to maximize $\eta_{\text {T }}$.

(2) Complete removal of decomposition products from the thermoelectric electrodes and complete transport of these products to the fuel-cell electrodes are necessary to maximize $\eta_{\mathrm{E}}$.

(3) Efficient fuel-cell electrodes are required to maximize $\eta_{F^{*}}$

Fuel cells can be made to operate at high efficiencies ( $\eta_{F}$ of 50 to 80 percent). It is conceivable that transport of the decomposition products from the thermoelectric to the fuel-cell electrodes can be accomplished with an efficiency $\eta_{\mathrm{F}}$ approaching 100 percent. Such high efficiencies, however, are not likely for the first step, thermoelectric conversion of heat to electricity. The efficiency of the thermoelectric conversion process $\eta_{T}$ is limited by the Carnot cycle efficiency and by the thermoelectric figure of merit. The Carnot cycle efficiency is a fundamental limit about which nothing can be done except to operate over the largest possible temperature difference. The thermoelectric figure of merit is a property of the material and can be made large by appropriate doping and by choice of material. The thermoelectric figure of merit $\mathrm{Z}$ is defined (ref. 3) as follows:

$$
\mathrm{Z}=\frac{\left(\frac{\Delta \varphi}{\Delta \mathrm{T}}\right)^{2} \sigma}{\mathrm{K}}
$$

where

$\frac{\Delta \varphi}{\triangle \Gamma} \quad$ thermoelectric power, $v /{ }^{\circ} \mathrm{C}$

$\triangle \varphi \quad$ open circuit voltage, $\mathrm{v}$ 


T temperature, ${ }^{\circ} \mathrm{C}$
$\sigma \quad$ specific electrical conductivity, $\left(\mathrm{ohm}^{-1}\right)\left(\mathrm{cm}^{-1}\right)$
$\mathrm{K}$ specific thermal conductivity, $\mathrm{w} /\left({ }^{\circ} \mathrm{C}\right)(\mathrm{cm})$

Typical values for the electrical conductivity of molten salts are in the range 2 to 5 per ohm centimeter. Although data for the thermal conductivity of molten-salt systems are scarce, a value of 0.008 watt per ${ }^{\circ} \mathrm{C}$ centimeter does not seem unreasonable. If an average value of $6 \times 10^{-4}$ volt per ${ }^{\circ}$ is taken for the thermoelectric power $(\Delta \varphi / \Delta T), 4$ per ohm centimeter for electrical conductivity, and 0.008 watt per ${ }^{\circ} \mathrm{C}$ centimeter for the specific thermal conductivity, the figure of merit $Z$ is $2 \times 10^{-4}$ per $O_{K}$. This estimated value of $Z$ is within an order of magnitude of the best semiconductor thermoelectric materials, for which $\mathrm{Z} \approx 2 \times 10^{-3}$ per ${ }^{\circ} \mathrm{K}$ (ref. 3 ). It is possible by screening a variety of molten-salt systems, that some molten-salt systems might be found with excellent figures of merit; consequently, high efficiency of the thermoelectric conversion process in the fused-salt cell can result.

\section{CHOICE OF SALTS FOR TEESTS}

In order to test the concept just outlined, it is necessary to choose suitable salts. A number of salts were screened by taking rough measurements of their thermoelectric power by the techniques outlined in reference 2. Values of thermoelectric power ranging from 100 to 900 microvolts per ${ }^{\circ} \mathrm{C}$ were found. The salts tested are listed in the following table along with the polarities and, for a few salts for which accurate measurements were made, the magnitudes of the thermoelectric power. From these tests two salts, stannous

\begin{tabular}{|l|c|c|} 
Salt & $\begin{array}{c}\text { Polarity } \\
\text { at hot } \\
\text { junction }\end{array}$ & $\begin{array}{c}\text { Thermoelectric } \\
\text { power, } \\
\mu v /{ }^{\circ} \text { C }\end{array}$ \\
\hline Cadmium bromide & - & 846 \\
Cadmium chloride & - & 600 \\
Lead chloride & - & 349 \\
Zinc chloride & - & 432 \\
Lead bromide & - & -- \\
Zinc bromide & - & -- \\
Silver nitrate & - & -- \\
Silver chloride & + & -- \\
Silver bromide & + & -- \\
Silver Iodide & + & -- \\
Stannous chloride & + & -- \\
\hline
\end{tabular}
chloride $\left(\mathrm{SnCl}_{2}\right)$ and $\mathrm{ZnCl}_{2}$, were selected for trial in the thermoelectric fuel cell. In both cases the thermoelectric power is moderately high, the metal is insoluble in the salt (ref. 4), and the products of electrolysis (metal + chlorine) can easily be recombined in an electrolytic cell to yield electricity. An additional point of interest is that the salts are opposite in polarity.

\section{PROCEDURE}

The design of the molten-salt regenerative, thermoelectric fuel cell is shown in figure 2. The cell was made of heat-resistant glass, and the electrodes were either platinum or tungsten. (No difference in cell operation was noted for the two electrode materials.) The cell was filled under a vacuum with either $\mathrm{ZnCl}_{2}$ or $\mathrm{SnCl} 2$. The salts had been vacuum dried at $150^{\circ}$ to $200^{\circ} \mathrm{C}$, melted, filtered through glass wool, and washed with hydrogen chloride gas before they were used in the cell. After filling, 


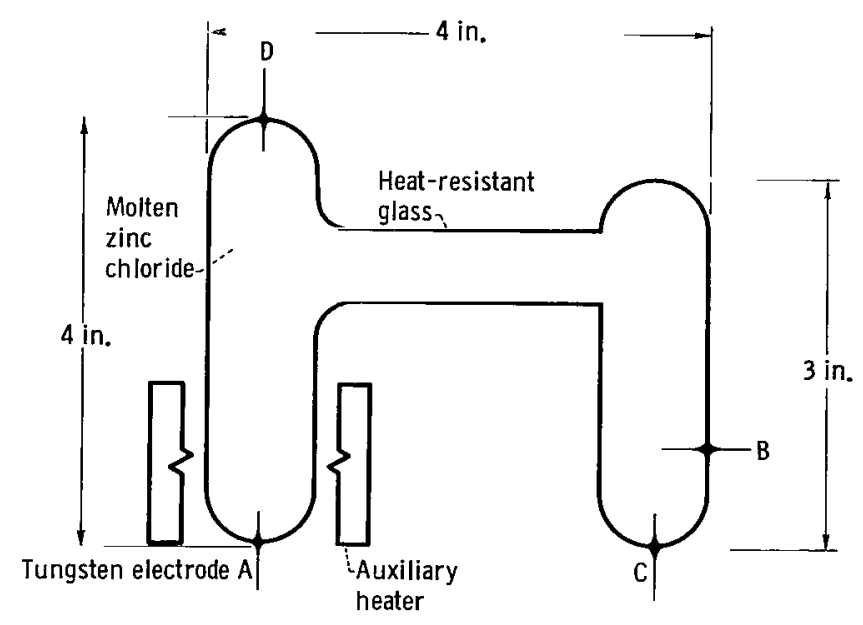

Figure 2. - Molten zinc chloride regenerative, thermoelectric fuel cell. the cell was placed in a rectangular furnace in which the temperature was controlled to $\pm 2^{\circ} \mathrm{C}$. An auxiliary resistance heater was wound around one leg of the cell to allow this leg to be heated to a temperature higher than the ambient furnace temperature. Temperatures of the hot leg of the cell and of the cooler parts of the cell were measured by platinum platinum-rhodium thermocouples.

The general plan of operation of the cell was as follows: the cell was heated in the furnace until the salt was molten (about $400^{\circ} \mathrm{C}$ ); the auxiliary heater was then used to raise the temperature of electrode $A$ $100^{\circ}$ to $200^{\circ} \mathrm{C}$ above that of the

other electrodes. As a result, a thermoelectric voltage appeared between electrodes $\mathrm{A}$ and $\mathrm{C}$. When these two electrodes were short-circuited, a small current flowed from $\mathrm{A}$ to $\mathrm{C}$ that caused electrolytic decomposition of the salt. The decomposition products moved by diffusion and convection to the vicinity of electrodes $D$ and $C$. As a result, a voltage appeared at these electrodes that could be used to do electrical work. The performance of electrical work caused a current to flow that regenerated the salt from its decomposition products.

\section{RESULTS}

When $\mathrm{ZnCl}_{2}$ was used in the cell, the hot electrode $\mathrm{A}$ was negative with respect to the cooler electrode $B$, as was expected from the thermoelectric power measurements. When the thermoelectric electrodes A and B were short-circuited, a current ranging from $10^{-6}$ to $10^{-5}$ ampere flowed. After several hours of operation, black particles of metallic zinc appeared near the cooler electrode, and the salt around the hot junction turned yellow because of the dissolved chlorine. The appearance of the zinc particles and the dissolved chlorine is evidence that the thermoelectric current had decomposed the salt. The decomposition products also diffused to the electrochemical-cell electrodes $\mathrm{C}$ and D; a voltage of 0.2 volt appeared at these electrodes as a result. Electrode D was in contact with free chlorine and electrode $\mathrm{C}$ was in contact with free zinc. Electrode $D$ was positive with respect to electrode $\mathrm{C}$ as was expected. When electrodes $\mathrm{C}$ and $\mathrm{D}$ were short-circuited, a current of about $10^{-3}$ ampere flowed.

The half-cell reactions were

Electrode A (hot electrode):

$$
2 \mathrm{Cl}^{-} \rightarrow \mathrm{Cl}_{2}+2 e
$$


Electrode B:

$$
\mathrm{Zn}^{++}+2 \mathrm{e} \rightarrow \mathrm{Zn}
$$

Electrode $\mathrm{C}$ :

$$
\mathrm{Zn}+\mathrm{Zn}^{++}+2 e
$$

Ellectrode D:

$$
2 \mathrm{Cl}+2 \mathrm{e} \rightarrow 2 \mathrm{Cl}^{-}
$$

Similar results were observed for $\mathrm{SnCl}_{2}$, but the polarity of all the electrodes was opposite to that for $\mathrm{ZnCl}_{2}$ because of the opposite polarity of the thermoelectric effect. Chlorine generated from the thermoelectric current appeared to react with the $\mathrm{SnCl}_{2}$ to form $\mathrm{SnCl}_{4}$ rather than simply to dissolve in the melt. In this case, the half-cell reactions were

Electrode A (hot electrode):

$$
\mathrm{Sn}^{++}+2 \mathrm{e} \rightarrow \mathrm{Sn}
$$

Electrode B:

$$
\mathrm{SnCl}_{2}+2 \mathrm{Cl}^{-} \rightarrow \mathrm{SnCl}_{4}+2 \mathrm{e}
$$

Electrode C:

$$
\mathrm{SnCl}_{4}+2 e \rightarrow \mathrm{SnCl}_{2}+2 \mathrm{Cl}^{-}
$$

Electrode D:

$$
\mathrm{Sn} \rightarrow \mathrm{Sn}^{++}+2 \mathrm{e}
$$

An attempt was made to increase the thermoelectric currents by increasing the area of the thermoelectric electrodes. This proved to be only partially successful, since increasing the electrode areas by 100 percent increased the thermoelectric current by only 50 percent.

\section{CONCLUDING REMARKS}

The results show that a molten-salt regenerative thermoelectric fuel cell. can be made to function. The major limiting factor appears to be the low efficiency of the thermoelectric conversion process, as was evidenced by the Iow $\left(10^{-5}\right.$ to $\left.10^{-6} \mathrm{amp}\right)$ thermoelectric currents produced.

Future work on the cell might logically

(1) Seek molten salts having high thermoelectric figures of merit 
(2) Study the separation and transport of decomposition products to the fuel-cell electrodes

The insolubility of a metal in its molten halide can be an important factor because of the relative ease of separation and transport to the electrochemical electrode.

Lewis Research Center

National Aeronautics and Space Administration

Cleveland, Ohio, May 15, 1964

\section{REFERENCES}

1. Holtan, H., Mazur, P., and de Groot, S. R.: On the Theory of Thermocouples and Thermocells. Physica, vol. 19, 1953, pp. 1109-1118.

2. Greenberg, Jacob, Weber, Donald E., and Thaller, Lawrence H.: Thermopotential Measurements for Molten Cadmium Chloride, Cadmium Bromide, and Lead. Chloride. Jour. Phys. Chem., vol. 67, no. 11, Nov. 15, 1963, pp. 24882492.

3. Ioffe, A. F.: Semiconductor Thermoelements and Thermoelectric Cooling. Infosearch Ltd., London (England), 1957.

4. Delimarskii, Iu. K., and Markov, B. F.: Electrochemistry of Fused Salts. Sigma Press, Washington D. C., 1961. 
"The deronautical and space activities of the United States shall be conducted so as to contribute. . . to the expansion of buman knowledge of pbenomena in the atmospbere and space. The Administration shall provide for the widest practicable and appropriate dissemination of information concerning its activities and the results tbereof."

-National Aeronautics and Space Act of 1958

\section{NASA SCIENTIFIC AND TECHNICAL PUBLICATIONS}

TECHNICAL REPORTS: Scientific and technical information considered important, complete, and a lasting contribution to existing knowledge.

TECHNICAL NOTES: Information less broad in scope but nevertheless of importance as a contribution to existing knowledge.

TECHNICAL MEMORANDUMS: Information receiving limited distribution because of preliminary data, security classification, or other reasons.

CONTRACTOR REPORTS: Technical information generated in connection with a NASA contract or grant and released under NASA auspices.

TECHNICAL TRANSLATIONS: Information published in a foreign language considered to merit NASA distribution in English.

TECHNICAL REPRINTS: Information derived from NASA activities and initially published in the form of journal articles.

SPECIAL PUBLICATIONS: Information derived from or of value to NASA activities but not necessarily reporting the results of individual NASA-programmed scientific efforts. Publications include conference proceedings, monographs, data compilations, handbooks, sourcebooks, and special bibliographies.

Details on the availability of these publications may be obtained from:

SCIENTIFIC AND TECHNICAL INFORMATION DIVISION

NATIONAL AERONAUTICS AND SPACE ADMINISTRATION

Washington, D.C. 20546 